\title{
sciendo
}

\section{Interconfessional Marriage and Serbian Orthodox Church - A Parish Life Perspective from Diaspora}

\author{
MiHailo SMILJANIC
}

This essay illustrates situations in actual parish life in the diaspora, between juridical presumptions and everyday practice. Juridical grounds are based on canonical law of the Orthodox Church as well as on the Constitution and Acts of the Serbian Orthodox Church, which were formed between the World Wars and in the postwar period, thus being prepared for the multicultural surroundings of Yugoslavia. Multiculturalism is particularly accented in the diaspora. The text describes the juridical procedure and its consequences in parish life and gives a statistical overview of a parish in the diaspora.

Keywords: Orthodoxy, mixed marriage, juridical practice, diaspora, Austria

The text aims to illustrate the difference between ancient canonical law and parish practice. Canonical law marks the boundaries of the Church, which in turn are defined by Orthodox theology. The very worldview and way of life of the first millennium Christians is cast in Church canons.

In the Serbian Orthodox Church there are several juridical textbooks in use for seminary schools and faculties, such as Nikodim Milas, Pravoslavno crkveno pravo (1902), Branko Cisarz, Church Law (1973) and Dimso Peric, Church Law (1997). The oldest one, Milas, mentions mixed marriages - with heretics and schismatics - admitting that there were such marriages since ancient times, but that the Church, practically, merely tolerates them. Younger authors, Cisarz and Peric, express a more flexible attitude, which stands as a basis for juridical practice in the Serbian Church.

In the mentioned textbooks, the parts devoted to marriage start with an historical overview with canons of Ecumenical councils which endorse Orthodox marriages, and impose limitations to marriages with heretics and non-Christians. These books do state that the institution of marriage was accepted from the Roman law, which did not recognize a difference of religion as an obstacle, but only if one spouse was a member of a cult considered to be dangerous for the state (for instance - Christianity). This general attitude seems to have been inherited when the Church became part of the system,

\footnotetext{
${ }^{*}$ Mag. Mihailo Smiljanic, priest. Address: Serbisch Orthodoxe Kirche, Diözese von Österreich und der Schweiz, Veithgasse 3, A-1030 Wien, Austria; email: mihailosmiljanic@gmail.com.
} 
but the roles were changed. Avoiding mixing with heretics had its theological justification, but also its political reasons.

The modern standard procedure in the Serbian Church includes a premarital examination, where the parish priest should check whether the bride and the groom have adequate knowledge of Orthodox faith, of prayers, if they do understand the meaning of marriage and their marital obligations, are there any obstacles for the marriage (such as a blood-relation, under-age, lack of mutual consent), etc.

An additional prerequisite since the WWII is an obligation that the couple should already be joined in the civil marriage, because civil marriage is a necessary precondition. Discussions about the subject were held between the wars, but the final decision was reached only after WWII in post-war Communist Yugoslavia. This in turn makes it also more difficult to deny marriage in the Church to those couples who are already in a civil marriage but have some kind of obstacle by Church standards.

As for mixed marriages, in the juridical theory and practice of the Serbian Orthodox Church, a difference in confession is considered to be a so-called "removable obstacle" for marriage in some cases ( $\$ 23$ and $\$ 25$ of Marital regulations). This means that a potential non-Orthodox spouse must be a member of a Christian confession whose baptism is accepted as full - namely Roman Catholic Church, Old Catholic Church, Anglican Church, Lutheran Church, or Oriental Churches. No Church marriage with members of other Christian denominations let alone a Muslim, a Jew, or an atheist for instance is possible. However, no other standards are insisted upon, so these communities' acceptance for marriage grossly differ.

The non-Orthodox spouse must sign a statement that he or she will not create any obstacles to the Orthodox spouse's expression and practice of the faith, and that the children born in their marriage will be baptized and raised as Orthodox Christians.

The Orthodox spouse must submit a written application to the bishop for a permit to join such matrimony, and the afore-mentioned statement of the non-Orthodox spouse is added. Memberships in the Orthodox - and nonOrthodox - communities are documented with valid baptism-certificates. In some Serbian dioceses an additional certificate of confirmation is required.

All this procedure was developed theoretically and technically after WWI, when Serbs and their Church found themselves in a new, multinational state, where mixing of nations and religions was endorsed. In the end, the ideal of Orthodox Christian marriage is required only from (future) clerics. They are to preserve the ideal and to embody it and witness it in their personal lives. 
The first witness to the marriage must be an Orthodox Christian, but the second can be a member of these other denominations (presumably a friend or relative of the non-Orthodox spouse), which also requires a dispensation.

If there are no other obstacles, bishops usually permit such a marriage, and the wedding ceremony can be performed. After obtaining the approval from the bishop, the priest can make a pre-marital examination, and perform a wedding in due time. The wedding must be performed by an Orthodox priest in an Orthodox church, otherwise the marriage is not valid for the Serbian Church. Since it is separated from the Divine Liturgy (the marrying couple is not taking communion, but a symbolic glass of wine), the ceremony is done fully, just as if both spouses were Orthodox.

The modern diaspora of each nation is a specific situation. People are not emigrating looking for Christ and spiritual experiences and salvation, but looking for a better life and better opportunities. They immigrate into alien cultures they are trying to adapt to, bringing with them their habits and building different and new identities. Some are trying to preserve their original identity and customs, others trying to hide them. If their religious education and their faith are not complete and firm-and usually they are not - the danger of loss of faith and identity is real. Here the Church is in a difficult position between its missionary imperative (to witness the Orthodox faith to local people) and the need to support its own people to preserve their national identity.

There is another vast and universal challenge, not exclusively for the diaspora. Under the pressure of secularisation, traditional Christian values are put to a serious test. Such values as chastity or virginity seem to be forgotten or mocked for the worse, and in practically all cases the couple is already living together (which is for the Church a forbidden practice of concubinage), sometimes even already having children. When they come to church to ask about marriage, it is already too late to preach about virtues. The bride and groom are usually not virgins, and furthermore the relationship they are looking to sanctify most likely is not their first. Also, the idea of Christian love is not understood, and it is replaced with emotions and physical attraction. So, instead of questioning the bride and the groom at pre-marital test on their knowledge of Orthodoxy, the priest must use the opportunity (at least in part) to preach about basic human values, and to remind the couple that Christian virtues are the very basis of religious life, let alone truly Christian marriage.

It is not a surprise that demand for interconfessional marriages is becoming more frequent, especially in the diaspora. This puts the Church and 
its priests in a difficult position. Such requests usually come from persons who are baptized but are actually quite vaguely connected with the Church - rarely coming to services or taking part in activities, and even more rarely taking communion. Lent and prayer are usually just nouns in the vocabulary. Telling them that their choice is - or could turn out be - wrong would probably push them further away. And as we have seen, there is no juridical basis to turn them down, if their partner belongs to an acceptable community.

The very meaning of the marriage is often not clear to the marrying couple. Usually it is no more than an interesting ritual among frescoes and with unusual singing, accompanied with happenings copied from movies and magazines. This image of marriage is blurred, and its edges are not so sharp as one could expect. On one side, you have an ideal described in the textbooks, but on the other you have real life, contaminated with non-Christian ideas and ideals. In theory, you have two young, devoted and motivated Orthodox Christians, who want to enter holy matrimony, ready to take their roles in the marriage, family and parish life; in practice, you often have people who are not really interested in parish life, who take the Church as a mere tradition or even as a part of folklore, who are not sincerely commited to another person for life, and who are already living in a concubinage.

There is another theological question of utmost importance that we have to ask ourselves: what is actually a definite acceptance of a relationship by the Church? In fact, this is not marital the sacrament of marriage. By the most ancient theological and liturgical practice of the beliefs of the Orthodox Church, the behaviour - and relationships - of a person are accepted with communion. Allowing a person to take communion means that this person is on good terms with the Church. If a person lives in a civil or interconfessional marriage, communion practically means accepting such a relationship. Imposing a heavy repentance - as Saint Basil the Great would do - for living in a concubinage is not something that Christians nowadays could or would bear. Eventually, a priest will let such a person receive Communion, and then the issue is practically settled.

Parish life and practice in the diaspora relies naturally on the juridical basis of the Church and on the local legal system. We have already said that the juridical basis was formed to support multicultural tendencies of the Kingdom of Yugoslavia, so it is ready-made to adapt to conditions in the diaspora.

The church where I serve was established in 2002. I searched the archives from 2003 to 2017, 15 years. In this time there was 238 marriages. Of that number 18 (7,56\%) were with Roman-Catholics, and 3 (1,26\%) with Evangelicals. Marriages with Evangelicals are actually rather frequent, taking in account official statistics that there are 5.110.000 Roman-Catholics, and 
297.838 Evangelicals (at the end of 2017) in Austria. There are 17 times more Roman-Catholics, but less than 6 times more mixed marriages. This marital statistic suggests a still quite strong inward orientation of the Serbian Orthodox community, and strong ties with the countries of origin.

It should be added that not in all cases of Orthodox marriages both spouses were born or originally baptised as Orthodox Christians. There are cases of pre-marital conversions to Orthodoxy, but it was not possible to track them through the register. As I have checked, even the fact that a spouse is non-Orthodox and that the marriage was dispensated is usually not mentioned in the note in the register, let alone the pre-marital conversions. However, priests usually try to discourage these conversions if they are not from sincerely religious, but from emotional or practical reasons. Those who want to convert to Orthodoxy have to write a plea with explanation, and wait for the approval of the bishop.

Obligatory civil marriage is additionally pointed out, because a Church wedding is a valid marital document in Austria and could raise legal issues for the priest and even for the Church (it could be added to a citizenship request, for instance, as a proof that a person was living in Austria with an Austrian citizen).

In the times of the postmodern barbarism and apostasy, our prime goal seems to be insisting on basic Christian values and virtues from the early age of our believers, religious education, and evangelisation of peoples' lives, before they come into a situation to choose their spouse. Founding a healthy religious life and reasoning would be a solution - not only for marital issues, but for many problems.

At the end, taking everything said into account, we can conclude that the marriage is the only truly ecumenical institution in our Church, not influenced by such questions as dogmatic differences, calendars or schisms. 